\title{
Realizacja polityki rozwoju województwa mazowieckiego w latach 1998-2018
}

\author{
Adam Struzik
}

\section{STRESZCZENIE}

Celem artykułu jest przegląd polityki rozwoju województwa mazowieckiego na przestrzeni ostatnich dwudziestu lat. W artykule omówiono reformę podziału administracyjnego Polski wprowadzoną na przełomie 1998 i 1999 roku oraz zmiany legislacyjne determinujące zakres kompetencji samorządu województwa w zakresie prowadzenia polityki rozwoju. Następnie przedstawiono zintegrowaną politykę rozwoju realizowaną w województwie mazowieckim w ujęciu horyzontalnym (integracja dokumentów strategicznych i planistycznych) oraz historycznym (konsekwencja w ustalaniu i realizacji celów rozwoju). Praktyka wdrażania polityki rozwoju została zestawiona z problemami wynikającymi z subwencji regionalnej (tzw. "janosikowego"). Wskazano przy tym na postępy w zakresie naprawy wadliwego mechanizmu redystrybucji środków między województwami. Kwestia dystrybucji środków z poziomu unijnego została wspomniana przy omawianiu zmian w podziale statystycznym województwa (na jednostki NUTS- 2), jako że jest to czynnik mający bezpośredni wpływ na wysokość i rodzaj wsparcia w ramach polityki spójności. Poza działalnością na poziomie Unii Europejskiej, omówiono współpracę województwa mazowieckiego z innymi regionami i instytucjami na poziomie międzynarodowym. W ostatniej części artykułu przedstawiono efekty realizacji polityki rozwoju województwa mazowieckiego w latach 1998-2018. Działania realizowane w poszczególnych okresach zilustrowano przykładami najważniejszych inwestycji i projektów oraz zestawiono z aktualnymi dokumentami wdrożeniowymi.

Artykuł został przygotowany na podstawie analizy danych i informacji zebranych w Mazowieckim Biurze Planowania Regionalnego w Warszawie. Zestawienie w jednym miejscu informacji na temat dwudziestu lat funkcjonowania Samorządu Województwa Mazowieckiego pozwoliło na przedstawienie, z nowej perspektywy, efektów i wartości dodanej prowadzenia konsekwentnej polityki rozwoju w regionie.

Słowa kluczowe: rozwój regionalny, samorząd terytorialny, polityka rozwoju, województwo mazowieckie

\section{Reforma podziału administracyjnego i nowe przepisy prawne}

Ustalona na poziomie prawnym w roku 1998, a wprowadzona w 1999 reforma administracyjna kraju upodmiotowiła polskie regiony, przez co wzmocniła skuteczność polityki regionalnej. W miejsce 49 województw zostało powołanych 16. Reforma delegowała część władzy wykonawczej i planistycznej samorządom regionalnym. Ustawa o samorządzie województwa ${ }^{1}$ określiła zakres obowiązków i kompetencji samorządów wojewódzkich. Organem stanowiącym i kontrolnym samorządu województwa stał się sejmik województwa, zaś wykonawczym zarząd województwa. W przyjętych założeniach podziału terytorialnego za istotne uznano ,takie ukształtowanie województw, by byty one zdolne do nawiąywania partnerskiej wspótpracy gospodarczej i kulturowej z jednostkami terytorialnymi w krajach członkowskich Unii

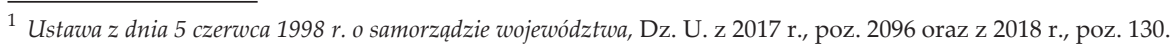


Europejskiej oraz strukturami Unii (by były podmiotami zdolnymi do korzystania z instrumentów polityki regionalnej Unii)"2.

Samorząd województwa prowadzi politykę rozwoju na podstawie strategii, która obejmuje m.in. zapewnienie trwałego i zrównoważonego rozwoju, wzrost konkurencyjności i innowacyjności gospodarki, zachowanie wartości środowiska przyrodniczego oraz kształtowanie i utrzymanie ładu przestrzennego województwa. W prowadzeniu polityki rozwoju samorządu województwa ważną rolę odgrywa plan zagospodarowania przestrzennego województwa ${ }^{3}$.

Samorząd województwa mazowieckiego od początku doceniał znaczenie strategicznego, zintegrowanego podejścia do zagadnień związanych z polityką rozwoju, której celem jest budowa innowacyjnego, konkurencyjnego i spójnego terytorialnie regionu. Dążąc do zapewnienia optymalnych warunków życia mieszkańców Mazowsza, samorząd województwa już w 1999 r. utworzył Mazowieckie Biuro Planowania Przestrzennego i Rozwoju Regionalnego w Warszawie. W tej wyspecjalizowanej jednostce po raz pierwszy w Polsce zastosowano zintegrowane podejście do planowania przestrzennego oraz programowania regionalnego, ujmując je w jeden spójny proces. Biuro to funkcjonuje do dziś, tyle że pod zmienioną nazwą - Mazowieckiego Biura Planowania Regionalnego w Warszawie (MBPR). Już w styczniu 2001 r., dzięki pracom MBPR, została uchwalona pierwsza Strategia rozwoju województwa mazowieckiego, a trzy lata później Plan zagospodarowania przestrzennego województwa mazowieckiego (PZPWM).

Samorząd województwa mógł jedynie w umiarkowanym stopniu wpływać na zagospodarowanie regionu - PZPWM od początku nie był aktem normatywnym. Nie zmieniła tego nowa ustawa o planowaniu i zagospodarowaniu przestrzennym (z 2003 r.), mimo że nadal jako zadanie samorządu województwa utrzymała kształtowanie i prowadzenie polityki przestrzennej. Samorząd regionalny może wpływać na zagospodarowanie przestrzenne na etapie uzgadniania gminnych dokumentów planistycznych pod kątem ich zgodności z planem wojewódzkim oraz z zadaniami samorządowymi.

Najpóźniej wprowadzonym aktem prawnym regulującym zakres działalności samorządu województwa była przyjęta w 2006 r. ustawa o zasadach prowadzenia polityki rozwoju . Na mocy zapisów ustawy samorząd województwa stał się odpowiedzialny za efektywne wykorzystanie funduszy unijnych przeznaczonych na rozwój regionalny. Kluczowe dokumenty przygotowywane przez samorząd województwa - regionalne programy operacyjne (na lata 2007-2013, 2014-2020) pozwoliły na realizację wielu ważnych inwestycji infrastrukturalnych.

\footnotetext{
${ }^{2}$ Ocena nowego zasadniczego podziału terytorialnego państwa przyjęta przez Radę Ministrów w dniu 12 grudnia 2000 r., przygotowana przez Ministerstwo Spraw Wewnętrznych i Administracji, Warszawa, Druk nr 538 z 14 grudnia 2000 r., Senat RP.

${ }^{3}$ Ustawa z dnia 27 marca 2003 r. o planowaniu i zagospodarowaniu przestrzennym, Dz.U. z 2017 r., poz. 1073, 1566.

${ }^{4}$ Ustawa z dnia 6 grudnia 2006 r. o zasadach prowadzenia polityki rozwoju, Dz.U. z 2017 r., poz., 1376, 1475.
} 


\section{Zintegrowana polityka rozwoju województwa mazowieckiego}

Strategia rozwoju województwa mazowieckiego i plan zagospodarowania przestrzennego województwa służą realizacji zintegrowanej polityki rozwoju (gospodarczego, społecznego, przestrzennego). Przejawia się to w zbieżności obszarów działań i celów rozwojowych określonych w aktualnej Strategii rozwoju województwa mazowieckiego do 2030 roku -Innowacyjne Mazowsze (SRWM 2030), przyjętej uchwałą nr 158/13 Sejmiku Województwa Mazowieckiego z dnia 28 października 2013 r. oraz polityk przestrzennych wskazanych w obowiązującym Planie zagospodarowania przestrzennego województwa mazowieckiego (PZPWM), przyjętym uchwałą nr 180/14 Sejmiku Województwa Mazowieckiego z dnia 7 lipca 2014 r. ${ }^{5}$ Poza wymiarem kierunkowym w obu dokumentach wskazano kluczowe obszary wsparcia: w przypadku SRWM 2030 są to obszary strategicznej interwencji, a w przypadku PZPWM obszary problemowe i funkcjonalne (tabela 1).

Tabela 1. Zgodność polityki rozwoju w głównych dokumentach strategicznych i planistycznych województwa mazowieckiego

\begin{tabular}{|c|c|}
\hline $\begin{array}{l}\text { Strategia rozwoju województwa } \\
\text { mazowieckiego do } 2030 \text { roku - Innowacyjne } \\
\text { Mazowsze - obszary działań i cele rozwojowe }\end{array}$ & $\begin{array}{l}\text { Plan zagospodarowania przestrzennego województwa } \\
\text { mazowieckiego - polityki przestrzenne (2014 r.) }\end{array}$ \\
\hline $\begin{array}{l}\text { Przemysł i produkcja } \\
\text { Rozwój produkcji ukierunkowanej na } \\
\text { eksport w przemyśle zaawansowanych } \\
\text { i średniozaawansowanych technologii } \\
\text { oraz w przemyśle i przetwórstwie rolno- } \\
\text { spożywczym }\end{array}$ & $\begin{array}{l}\text { Rozwój przemysłu } \\
\text { Rozwój i modernizacja obszarów wiejskich }\end{array}$ \\
\hline $\begin{array}{l}\text { Środowisko i energetyka } \\
\text { Zapewnienie gospodarce regionu } \\
\text { zdywersyfikowanego zaopatrzenia w energię } \\
\text { przy zrównoważonym gospodarowaniu } \\
\text { zasobami środowiska }\end{array}$ & $\begin{array}{l}\text { Rozwój systemów infrastruktury technicznej } \\
\text { Poprawa odporności na zagrożenia naturalne } \\
\text { Kształtowanie i ochrona zasobów i walorów } \\
\text { przyrodniczych oraz poprawy standardów środowiska }\end{array}$ \\
\hline $\begin{array}{l}\text { Gospodarka } \\
\text { Wzrost konkurencyjności regionu poprzez } \\
\text { rozwój działalności gospodarczej oraz transfer } \\
\text { i wykorzystanie nowych technologii }\end{array}$ & $\begin{array}{l}\text { Poprawa struktury przestrzennej i funkcjonalnej } \\
\text { województwa } \\
\text { Wzrost konkurencyjności wybranych ośrodków } \\
\text { osadniczych } \\
\text { Rozwój i modernizacja obszarów wiejskich }\end{array}$ \\
\hline $\begin{array}{l}\text { Przestrzeń i transport } \\
\text { Poprawa dostępności i spójności } \\
\text { terytorialnej regionu oraz kształtowanie ładu } \\
\text { przestrzennego }\end{array}$ & $\begin{array}{l}\text { Poprawa dostępności i efektywności transportowej } \\
\text { [sieć transportowa (drogowa, kolejowa, rowerowa)] }\end{array}$ \\
\hline $\begin{array}{l}\text { Społeczeństwo } \\
\text { Poprawa jakości życia oraz wykorzystanie } \\
\text { kapitału ludzkiego i społecznego do tworzenia } \\
\text { nowoczesnej gospodarki }\end{array}$ & Wspieranie wzrostu bezpieczeństwa publicznego \\
\hline
\end{tabular}

\footnotetext{
${ }^{5}$ Dz.Urz. Woj. Maz. z 2014 r., poz. 6868.
} 
Tabela 1. cd. Zgodność polityki rozwoju w głównych dokumentach strategicznych i planistycznych województwa mazowieckiego

\begin{tabular}{|c|c|}
\hline $\begin{array}{l}\text { Strategia rozwoju województwa } \\
\text { mazowieckiego do } 2030 \text { roku - Innowacyjne } \\
\text { Mazowsze - obszary działań i cele rozwojowe }\end{array}$ & $\begin{array}{l}\text { Plan zagospodarowania przestrzennego województwa } \\
\text { mazowieckiego - polityki przestrzenne (2014 r.) }\end{array}$ \\
\hline $\begin{array}{l}\text { Kultura i dziedzictwo } \\
\text { Wykorzystanie potencjału kultury } \\
\text { i dziedzictwa kulturowego oraz walorów } \\
\text { środowiska przyrodniczego dla rozwoju } \\
\text { gospodarczego regionu i poprawy jakości } \\
\text { życia }\end{array}$ & $\begin{array}{l}\text { Poprawa dostępności i efektywności transportowej } \\
\text { [sieć transportowa (rowerowa)] } \\
\text { Opieka i ochrona dziedzictwa kulturowego i dóbr kultury } \\
\text { współczesnej } \\
\text { Wzrost atrakcyjności turystycznej województwa }\end{array}$ \\
\hline Obszary strategicznej interwencji (OSI) & $\begin{array}{l}\text { Wzrost konkurencyjności wybranych ośrodków } \\
\text { osadniczych } \\
\text { Obszary problemowe, obszary funkcjonalne }\end{array}$ \\
\hline
\end{tabular}

Źródło: opracowanie MBPR w Warszawie

Poza spójnością aktualnych dokumentów strategicznych i planistycznych, polityka rozwoju w województwie mazowieckim od początku charakteryzuje się konsekwencją. Jest to widoczne $\mathrm{w}$ ciągłości celów kolejnych aktualizacji podstawowego dokumentu strategicznego regionu, czyli strategii rozwoju województwa (tabela 2).

Tabela 2. Cele polityki rozwoju w województwie mazowieckim ujęte w trzech strategiach województwa - porównanie

\begin{tabular}{|c|c|c|}
\hline $\begin{array}{l}\text { Strategia rozwoju województwa } \\
\text { mazowieckiego (z } 2001 \text { r.) - cele } \\
\text { długookresowe i średniookresowe }\end{array}$ & $\begin{array}{l}\text { Strategia rozwoju } \\
\text { województwa mazowieckiego } \\
\text { do roku } 2020 \text { (aktualizacja) - } \\
\text { cele pośrednie i kierunki działań }\end{array}$ & $\begin{array}{l}\text { Strategia rozwoju województwa } \\
\text { mazowieckiego do } 2030 \text { roku } \\
\text { - Innowacyjne Mazowsze - } \\
\text { obszary działań i cele rozwojowe }\end{array}$ \\
\hline $\begin{array}{l}\text { Przyspieszenie procesów rozwoju } \\
\text { społeczno-gospodarczego } \\
\text { opartego na wiedzy i innowacjach }\end{array}$ & $\begin{array}{l}\text { Wzrost innowacyjności } \\
\text { i konkurencyjności gospodarki } \\
\text { regionu (w tym rozwój } \\
\text { nowoczesnych technologii) }\end{array}$ & $\begin{array}{l}\text { Przemysł i produkcja } \\
\text { Rozwój produkcji } \\
\text { ukierunkowanej na eksport } \\
\text { w przemyśle zaawansowanych } \\
\text { i średniozaawansowanych } \\
\text { technologii oraz w przemyśle } \\
\text { i przetwórstwie rolno- } \\
\text { spożywczym }\end{array}$ \\
\hline $\begin{array}{l}\text { Aktywizacja i modernizacja } \\
\text { obszarów pozametropolitalnych } \\
\text { (w tym wspieranie rozwoju } \\
\text { przetwórstwa rolno-spożywczego) }\end{array}$ & $\begin{array}{l}\text { Stymulowanie rozwoju funkcji } \\
\text { metropolitalnych Warszawy } \\
\text { (w tym przeciwdziałanie } \\
\text { degradacji środowiska } \\
\text { oraz rozwój infrastruktury } \\
\text { technicznej) }\end{array}$ & $\begin{array}{l}\text { Środowisko i energetyka } \\
\text { Zapewnienie gospodarce } \\
\text { regionu zdywersyfikowanego } \\
\text { zaopatrzenia w energię } \\
\text { przy zrównoważonym } \\
\text { gospodarowaniu zasobami } \\
\text { środowiska }\end{array}$ \\
\hline
\end{tabular}




\begin{tabular}{|c|c|c|}
\hline $\begin{array}{l}\text { Przyspieszenie procesów rozwoju } \\
\text { społeczno-gospodarczego } \\
\text { opartego na wiedzy i innowacjach }\end{array}$ & $\begin{array}{l}\text { Wzrost innowacyjności } \\
\text { i konkurencyjności gospodarki } \\
\text { regionu }\end{array}$ & $\begin{array}{l}\text { Gospodarka } \\
\text { Wzrost konkurencyjności regionu } \\
\text { poprzez rozwój działalności } \\
\text { gospodarczej oraz transfer } \\
\text { i wykorzystanie nowych } \\
\text { technologii }\end{array}$ \\
\hline $\begin{array}{l}\text { Wzmocnienie mechanizmów } \\
\text { dyfuzji procesów rozwojowych } \\
\text { z aglomeracji warszawskiej na } \\
\text { otoczenie regionalne (w tym } \\
\text { modernizacja regionalnego } \\
\text { systemu transportowego) } \\
\text { Zahamowanie narastania } \\
\text { chaosu w przestrzennym } \\
\text { zagospodarowaniu Warszawy } \\
\text { i województwa }\end{array}$ & $\begin{array}{l}\text { Stymulowanie rozwoju } \\
\text { funkcji metropolitalnych } \\
\text { Warszawy (w tym wzmocnienie } \\
\text { powiązań Warszawy } \\
\text { z otoczeniem i zahamowanie } \\
\text { chaosu w przestrzennym } \\
\text { zagospodarowaniu) } \\
\text { Aktywizacja } \\
\text { i modernizacja obszarów } \\
\text { pozametropolitalnych } \\
\text { (w tym poprawa dostępności } \\
\text { komunikacyjnej) }\end{array}$ & $\begin{array}{l}\text { Przestrzeń i transport } \\
\text { Poprawa dostępności } \\
\text { i spójności terytorialnej regionu } \\
\text { oraz kształtowanie ładu } \\
\text { przestrzennego }\end{array}$ \\
\hline $\begin{array}{l}\text { Wzmocnienie regionalnych } \\
\text { więzi kulturowo-społecznych } \\
\text { mieszkańców województwa } \\
\text { mazowieckiego } \\
\text { Poprawa stanu zdrowia } \\
\text { mieszkańców województwa } \\
\text { mazowieckiego }\end{array}$ & $\begin{array}{l}\text { Rozwój kapitału społecznego } \\
\text { Rozwój społeczeństwa } \\
\text { obywatelskiego oraz } \\
\text { kształtowanie wizerunku } \\
\text { regionu }\end{array}$ & $\begin{array}{l}\text { Społeczeństwo } \\
\text { Poprawa jakości życia oraz } \\
\text { wykorzystanie kapitału ludzkiego } \\
\text { i społecznego do tworzenia } \\
\text { nowoczesnej gospodarki }\end{array}$ \\
\hline $\begin{array}{l}\text { Przeciwdziałanie degradacji } \\
\text { i rewaloryzacja środowiska } \\
\text { przyrodniczego }\end{array}$ & $\begin{array}{l}\text { Aktywizacja } \\
\text { i modernizacja obszarów } \\
\text { pozametropolitalnych (w tym } \\
\text { ochrona i rewaloryzacja } \\
\text { środowiska przyrodniczego) }\end{array}$ & $\begin{array}{l}\text { Środowisko i energetyka } \\
\text { Zapewnienie gospodarce } \\
\text { regionu zdywersyfikowanego } \\
\text { zaopatrzenia w energię } \\
\text { przy zrównoważonym } \\
\text { gospodarowaniu zasobami } \\
\text { środowiska }\end{array}$ \\
\hline $\begin{array}{l}\text { Wzmocnienie regionalnych } \\
\text { więzi kulturowo-społecznych } \\
\text { mieszkańców województwa } \\
\text { mazowieckiego (w tym ochrona } \\
\text { dóbr kultury i wspieranie } \\
\text { twórczości artystycznej) }\end{array}$ & $\begin{array}{l}\text { Rozwój społeczeństwa } \\
\text { obywatelskiego oraz } \\
\text { kształtowanie wizerunku } \\
\text { regionu (w tym promocja } \\
\text { i zwiększanie atrakcyjności } \\
\text { turystycznej regionu) }\end{array}$ & $\begin{array}{l}\text { Kultura i dziedzictwo } \\
\text { Wykorzystanie potencjału kultury } \\
\text { i dziedzictwa kulturowego } \\
\text { oraz walorów środowiska } \\
\text { przyrodniczego dla rozwoju } \\
\text { gospodarczego regionu } \\
\text { i poprawy jakości życia }\end{array}$ \\
\hline $\begin{array}{l}\text { Wzmocnienie istniejących } \\
\text { i stymulowanie rozwoju nowych } \\
\text { funkcji metropolitalnych } \\
\text { Warszawy } \\
\text { Aktywizacja i modernizacja } \\
\text { obszarów pozametropolitalnych }\end{array}$ & $\begin{array}{l}\text { Stymulowanie rozwoju funkcji } \\
\text { metropolitalnych Warszawy } \\
\text { Aktywizacja } \\
\text { i modernizacja obszarów } \\
\text { pozametropolitalnych }\end{array}$ & $\begin{array}{l}\text { Obszary strategicznej } \\
\text { interwencji }\end{array}$ \\
\hline
\end{tabular}

Źródło: opracowanie MBPR w Warszawie 


\section{Rozwój województwa mazowieckiego a subwencja regionalna}

Jedną z istotnych barier, które stanęły na drodze wdrażania polityki rozwoju województwa, był system subwencji regionalnej, znanej też jako „janosikowe". Przyjęta w 2003 r. ustawa o dochodach jednostek samorzadu terytorialnego wprowadziła mechanizm przekazywania dochodów wypracowanych w województwach o wyższych dochodach do tych, w których wpływy z podatków są niższe. Algorytm wyliczania wpłaty został przy tym skonstruowany w taki sposób, że niemal cały przyrost dochodów efektywnie rozwijającego się województwa powyżej pewnego poziomu był odprowadzany do budżetu państwa.

Nie uwzględniano przy tym bieżącej sytuacji gospodarczej, a dochody samorządów obliczano na podstawie danych sprzed dwóch lat. W efekcie problem janosikowego stał się szczególnie dotkliwy w okresie kryzysu gospodarczego, poprzedzonego latami szybkiego przyrostu gospodarczego. Skala problemu była widoczna w rzeczywistych dochodach województwa mazowieckiego w przeliczeniu na mieszkańca. Przykładowo w 2011 r., po uwzględnieniu korekty czasowej wpłat i wypłat subwencji regionalnej, kształtowały się one na poziomie poniżej 400 zł, czyli były jednymi z najniższych w kraju. Mając na uwadze powyższe, prężnie rozwijające się Mazowsze i cechujące się jednymi z najniższych kosztów utrzymania administracji w przeliczeniu na 1 mieszkańca, musiało zaciągać kredyty na bieżącą działalność.

Odbieranie dochodów województwa mazowieckiego na potrzeby subwencji regionalnej znacząco utrudniało prowadzenie polityki rozwoju, w tym zwłaszcza realizację inwestycji. Zagrożone były nie tylko inwestycje w całości finansowane ze środków własnych województwa, lecz również realizowane $\mathrm{w}$ ramach polityki spójności, brakowało bowiem środków na wkład własny województwa. Konieczna była naprawa mechanizmu wyrównywania dochodów między województwami.

Starania Samorządu Województwa Mazowieckiego, przy wsparciu merytorycznym Mazowieckiego Biura Planowania Regionalnego, doprowadziły do zmian w systemie. W marcu 2014 r. zapadł kluczowy wyrok Trybunału Konstytucyjnego, który potwierdził, że przepisy dotyczące subwencji regionalnej są niezgodne z Konstytucją RP, ponieważ nie gwarantują województwu zachowania istotnej części dochodów na realizację zadań własnych. W efekcie wprowadzone zostały zmiany w systemie pobierania opłat, przynajmniej częściowo naprawiające błędy w ustawie o dochodach jednostek samorządu terytorialnego ${ }^{6}$, aczkolwiek mają one charakter tymczasowy. Kolejne prowizoryczne rozwiązania były przedłużane, ostatni raz do 2019 r. Należy liczyć, że systemowe zmiany zostaną w końcu wprowadzone na stałe. Tym bardziej, że stołeczne funkcje Warszawy, największej aglomeracji w Polsce, wymagają większych nakładów na rozwiązania infrastrukturalne (metro, obwodnice, poprawa bezpieczeństwa energetycznego), ochronę środowiska czy poprawę jakości powietrza.

6 Ustawa z dnia 13 listopada 2003 r. o dochodach jednostek samorzadu terytorialnego (Dz.U. z 2016 r. poz. 198 i 1609). 


\section{Podział statystyczny województwa mazowieckiego}

W 2000 r. został wprowadzony polski statystyczny podział terytorialny kraju dostosowany do zasad stosowanych przez Eurostat (tj. Klasyfikacji Jednostek Terytorialnych do Celów Statystycznych - NUTS). Dynamiczny rozwój województwa mazowieckiego i jego zróżnicowanie wewnętrzne spowodowały, że uśrednione wskaźniki ogólnowojewódzkie nie odzwierciedlały rzeczywistej sytuacji w odniesieniu do obszarów pozametropolitalnych i mogły wprowadzać w błąd.

Z badań Europejskiego Urzędu Statystycznego wynika, że w latach 2008-2014 województwo mazowieckie uzyskało najwyższy wzrost PKB na 1 mieszkańca, o około 25 p.p., z poziomu $85 \%$ średniej UE do 109\%. Mazowieckie uzyskało wyższy poziom rozwoju od średniej unijnej, wyprzedzając 275 regionów i znalazło się w pierwszej piątce najszybciej rozwijających się regionów Unii.

Zakwalifikowanie, na podstawie danych ogólnowojewódzkich, całego Mazowsza do kategorii lepiej rozwiniętych skutkowałoby zdecydowanym ograniczeniem środków na inwestycje infrastrukturalne. W związku z tym, już na początku poprzedniej perspektywy finansowej, samorząd województwa zabiegał o nowy podział statystyczny, uwzględniający wewnętrzne zróżnicowanie regionu. Jako że zmiana ta nie doszła do skutku przed perspektywą 2014-2020, "Rząd Rzeczypospolitej Polskiej zdecydowat [...] o zminimalizowaniu negatywnych skutków zakwalifikowania [województwa mazowieckiego] do regionów lepiej rozwiniętych poprzez zwiększenie jego alokacji o petne 3\%" 7 .

W 2015 r. zespół rządowo-samorządowy wypracował „założenia modyfikacji podziału statystycznego" przyjęte przez rząd, a następnie przez Komisję Europejską. Tym samym województwo mazowieckie od stycznia 2018 r. jest formalnie makroregionem NUTS-1, składającym się z dwóch regionów NUTS-2: regionu warszawskiego stołecznego obejmującego Warszawę wraz z dziewięcioma powiatami oraz regionu mazowieckiego regionalnego - obejmującego pozostałą część województwa. Podział ten umożliwi dostosowanie wysokości i rodzaju wsparcia z funduszy unijnych do poszczególnych części województwa. Nowy podział na jednostki NUTS-2 zapewnia bowiem zdecydowanie bardziej obiektywną ilustrację sytuacji społeczno-gospodarczej na Mazowszu, uwzględniającą znaczące dysproporcje $\mathrm{w}$ poziomie PKB pomiędzy poszczególnymi podregionami województwa. Otoczenie stolicy cechuje się poziomem PKB na 1 mieszkańca zdecydowanie powyżej średniej unijnej, podczas gdy pozostała część województwa plasuje się wyraźnie poniżej progu 75\% średniej UE. Wprowadzenie nowego podziału statystycznego daje możliwość zróżnicowania interwencji po 2020 r. Pozwoli to na zapewnienie wyższego stopnia dofinansowania $\mathrm{w}$ ramach wsparcia skierowanego do obszarów problemowych wyznaczonych w SRWM 2030.

\footnotetext{
${ }^{7}$ Programowanie perspektywy finansowej 2014-2020 - Umowa Partnerstwa, Ministerstwo Infrastruktury i Rozwoju, 2014.
} 


\section{Współpraca międzynarodowa województwa mazowieckiego}

Jak zaznaczono na wstępie, jednym z celów reformy administracyjnej było umożliwienie sprawnej współpracy międzynarodowej na poziomie regionalnym. Od 2002 r. województwo mazowieckie ma swoje biuro przedstawicielskie w Brukseli, a od 2006 r. konsekwentnie prowadzi współpracę międzynarodową, zgodnie z przyjętymi przez sejmik priorytetami współpracy zagranicznej. Partnerskie kontakty międzyregionalne nawiązywane i utrzymywane są z regionami Europy i Azji (Chiny, Korea, Indie). Służą one rozwojowi współpracy gospodarczej, wymianie informacji i doświadczeń oraz tworzeniu korzystnych warunków do współpracy podmiotów gospodarczych i organizacji społecznych. Województwo mazowieckie ma aktualnie podpisanych 20 porozumień o współpracy oraz listy intencyjne: ze stanem Santa Catarina w Brazylii, z prowincją Gyeongsangbuk-do w Republice Korei oraz Stanem Gudżarat w Indiach. Prowadzona jest także współpraca, w ramach tzw. Małego Trójkąta Weimarskiego, na podstawie wspólnej deklaracji o współpracy pomiędzy województwem mazowieckim, Krajem Związkowym Brandenburgia i regionem Ile-de-France.

Poza współpracą dwustronna, Mazowsze stale współpracuje w ramach organizacji i instytucji międzynarodowych, zrzeszających samorządy terytorialne państw europejskich. Województwo mazowieckie jest reprezentowane, m.in. na forum: Konferencji Regionów Posiadających Porty Lotnicze (ARC), Europejskiej Platformie Regionów Podmiejskich (PURPLE), Sieci Regionów Europejskich Wykorzystujących Technologie Kosmiczne (NEREUS), Europejskiej Sieci Regionów Chemicznych (ECRN), Konferencji Środowiskowej Regionów Europy (ENCORE), Europejskiej Sieci Społecznej (ESN), Sieci Europejskich Regionów i Obszarów Metropolitalnych (METREX) oraz Forum Regionów Państw Grupy Wyszehradzkiej.

\section{Realizacja inwestycji na obszarze województwa mazowieckiego}

Po przeprowadzonej reformie administracyjnej województwa otrzymały kompetencje umożliwiające prowadzenie samodzielnej polityki rozwoju, w tym dzięki przeniesieniu wielu kompetencji na poziom regionalny oraz uzyskaniu niezależności finansowej w realizacji najważniejszych inwestycji w regionach. Prowadzona polityka samorządu opierała się na wcześniej przytoczonych strategiach rozwoju województwa. Zarówno strategie, jak i opracowywane na ich podstawie programy wojewódzkie i regionalne stanowiły podstawę prowadzenia polityki rozwoju na obszarze województwa, podejmowania decyzji w bieżącej działalności samorządu, zawierania kontraktów wojewódzkich i terytorialnych oraz aplikowania o środki pomocowe i wspólnotowe UE. Od początku utworzenia województwa, władze samorządowe ukierunkowane były na realizację inwestycji mających na celu zwiększenie konkurencyjności i spójności regionu. Ważną rolę odegrały programy 
wojewódzkie: Wojewódzki program rozwoju regionalnego Mazowsza na lata 2001-2006, Regionalny program operacyjny województwa mazowieckiego 2007-2013 oraz obecnie realizowany Regionalny program operacyjny województwa mazowieckiego 2014-2020.

W latach 1999-2002 dokonywane były ważne, wieloletnie inwestycje rozwojowe przy udziale dotacji z budżetu państwa - głównie w zakresie infrastruktury drogowej i ochrony zdrowia. Udzielone dotacje w wysokości 834,4 mln zł stanowiły ok. 16\% dotacji krajowych ${ }^{8}$.

W okresie przedakcesyjnym głównym dokumentem o charakterze średniookresowej strategii rozwoju był Wstęny Narodowy Plan Rozwoju 2000-2003 (WNPR)9. Plan ten realizowany był przez programy krajowe i regionalne. Instrumentami realizującymi WNPR były fundusze dostępne w przedakcesyjnych programach pomocowych Unii Europejskiej: PHARE - programie wspierającym przemiany gospodarcze i społeczne $\mathrm{w}$ krajach kandydujących, ISPA - wsparcia finansowego ze środków UE na realizację dużych inwestycji o zasięgu krajowym, związanych z rozwojem i modernizacją infrastruktury, ochrony środowiska i transportu oraz SAPARD - program na rzecz rozwoju rolnictwa i obszarów wiejskich.

W ramach PHARE 2000, 2001, 2002 w województwie mazowieckim przyznano dotacje dla 370 projektów na łączną kwotę prawie 6,1 mln euro. Łączna wartość wszystkich projektów zakwalifikowanych do wsparcia w ramach Programu wyniosła prawie 23,4 mln euro, a dotacje ze środków unijnych stanowiły $26 \%$ kosztów kwalifikowanych ${ }^{10}$.

Województwo mazowieckie, z pomocą środków z funduszu ISPA / Fundusz Spójności w obszarze środowisko, realizowało 6 dużych przedsięwzięć z zakresu infrastruktury ochrony środowiska o łącznej wartości 341,4 mln euro, dofinansowanych na ogólną kwotę 210,7 mln euro. Były to projekty dotyczące poprawy jakości wód powierzchniowych, polepszenia jakości i dystrybucji wody przeznaczonej do spożycia, racjonalizacja gospodarki odpadami, ochrona powierzchni ziemi ${ }^{11}$. Natomiast $\mathrm{w}$ obszarze transportu na terenie województwa zrealizowano inwestycje o całkowitej wartości 801,2 mln euro, dofinansowane na ogólną kwotę 578,7 mln euro ${ }^{12}$ (tabela 3).

\footnotetext{
${ }^{8}$ A. Młynarska-Witkowska, Informacja o dotacjach z budżetu państwa do inwestycji wieloletnich w latach $1999-2001$ oraz planowanych na 2002 r. w układzie wojewódzkim. Informacja nr 837 (IP-97G), Biuro Studiów i Ekspertyz Kancelarii Sejmu. ${ }^{9}$ Podstawowym aktem prawnym regulującym funkcjonowanie polityki regionalnej w Polsce w latach 2000-2004 była ustawa z dnia 12 maja $2000 \mathrm{r}$. o zasadach wspierania rozwoju regionalnego.

10 Wykorzystanie środków wsparcia w projektach rozwoju województwa mazowieckiego w latach 1999-2004, MBPPiRR, Warszawa 2005, s. 62-63, opracowanie niepublikowane.

11 Tamże, s. 27-28.

12 Tamże, s. 12-13.
} 
Tabela 3. Przykładowe projekty zrealizowane w okresie przedakcesyjnym 1999-2004

\begin{tabular}{|c|c|c|}
\hline Obszar & $\begin{array}{l}\text { Programy/ źródła } \\
\text { finansowania }\end{array}$ & Inwestycje (przykładowe) \\
\hline & $\begin{array}{l}\text { Dotacje budżetu } \\
\text { państwa }\end{array}$ & Wodociąg Północny w Warszawie \\
\hline $\begin{array}{l}\text { Infrastruktura } \\
\text { techniczna }\end{array}$ & $\begin{array}{l}\text { ISPA/Fundusz } \\
\text { Spójności }\end{array}$ & $\begin{array}{l}\text { Zrealizowano projekty: Zaopatrzenie w wodę i oczyszczanie } \\
\text { ścieków w Warszawie; Gospodarka odpadami komunalnymi } \\
\text { w Radomiu; Gospodarka wodno-ściekowa na terenie gminy } \\
\text { Grodzisk Mazowiecki oraz gm. Milanówek; Modernizacja } \\
\text { i rozbudowa systemu wodociągowo-kanalizacyjnego dla m. } \\
\text { Otwocka; Program uporządkowania gospodarki wodno-ściekowej } \\
\text { na terenie miasta i gminy Piaseczno; Modernizacja i rozbudowa } \\
\text { systemu zaopatrzenia w wodę i odprowadzanie ścieków dla } \\
\text { miasta Radomia }\end{array}$ \\
\hline \multirow{2}{*}{ Transport } & $\begin{array}{l}\text { Dotacje budżetu } \\
\text { państwa }\end{array}$ & $\begin{array}{l}\text { Dotacje zostały przeznaczone na następujące inwestycje: trasa } \\
\text { Armii Krajowej i aleja Prymasa 1000-lecia w Warszawie, ciąg ob- } \\
\text { wodnicowy Młodzieszyn - Sochaczew, obwodnica Białobrzegów } \\
\text { oraz I linia metra w Warszawie }\end{array}$ \\
\hline & $\begin{array}{l}\text { ISPA/Fundusz } \\
\text { Spójności }\end{array}$ & $\begin{array}{l}\text { Inwestycje dotyczyły modernizacji drogi nr } 50 \text { Grójec - } \\
\text { Sochaczew wraz z obwodnicą Mszczonowa oraz drogi krajowej nr } \\
50 \text { Grójec - Mińsk Mazowiecki; modernizację linii kolejowej E-20 } \\
\text { Mińsk Mazowiecki - Siedlce oraz linii kolejowej Siedlce - Terespol }\end{array}$ \\
\hline $\begin{array}{l}\text { Infrastruktura } \\
\text { społeczna }\end{array}$ & $\begin{array}{l}\text { Dotacje budżetu } \\
\text { państwa }\end{array}$ & $\begin{array}{l}\text { Szpitale w: Garwolinie, Grodzisku Mazowieckim, Przasnyszu, } \\
\text { Radomiu-Józefowie, Płocku i Ostrołęce }\end{array}$ \\
\hline
\end{tabular}

Źródło: opracowanie MBPR w Warszawie

Kontrakty wojewódzkie odegrały znaczącą rolę w procesie przygotowania Polski do absorbcji funduszy pomocowych i strukturalnych. W latach 2001-2004 realizowano inwestycje w zakresie I Kontraktu 2001-2003 i II Kontraktu na rok 2004, na łączną kwotę 1936,8 mln zł, z czego 1003,8 mln zł (52\%) środków pochodziło z budżetu państwa, a 931,6 $\mathrm{mln}$ zł (48\%) z budżetów jednostek samorządów terytorialnych. Wykonano 565 zadań (w tym 7 z inwestycji wieloletnich). Dzięki Kontraktom możliwa była budowa ok. 4 km pierwszej linii metra wraz z 4 stacjami; budowa Wodociągu Północnego zaopatrującego w wodę pitną wschodnią i północną część Warszawy; modernizacja infrastruktury komunalnej w aglomeracji warszawskiej; modernizacja oraz budowa ponad $130 \mathrm{~km}$ dróg powiatowych i gminnych (100 zadań); budowa 10 wielofunkcyjnych zbiorników wodnych na rzekach województwa; budowa i modernizacja 13 szpitali oraz domów opieki społecznej i placówek opiekuńczo-wychowawczych (31 zadań); budowa i modernizacja ponad 350 obiektów oświatowych; budowa centrum kultury w Ostrołęce, adaptacja obiektu na siedzibę Muzeum Mazowieckiego w Płocku oraz budowa hali sportowej dla Politechniki Radomskiej. ${ }^{13}$ Kontraktem wojewódzkim dla województwa mazowieckiego na lata 2005-2006 objęto projekty z dziedziny ochrony zdrowia i pomocy społecznej, na kwotę 44,9 mln zł. 
W latach 2004-2006 najważniejszą rolę odegrał Zintegrowany Program Operacyjny Rozwoju Regionalnego (ZPORR) ${ }^{14}$, który był realizowany na poziomie krajowym. Województwo mazowieckie otrzymało około $300 \mathrm{mln}$ euro. Środki te zostały przeznaczone głównie na rozwój transportu miejskiego w aglomeracji warszawskiej, modernizację dróg, urządzeń komunalnych, a także ochronę zdrowia, edukację, ekologię, naukę, kulturę, sztukę czy turystykę. Przykładowe projekty zrealizowane w ramach ZPORR przedstawiono w tabeli 4.

Tabela 4. Przykładowe projekty zrealizowane w ramach ZPORR

\begin{tabular}{|c|c|}
\hline Obszar & Inwestycje (przykładowe) \\
\hline Transport & $\begin{array}{l}\text { Ważne projekty dotyczyły inwestycji: } \\
\text { — Samorządu Województwa Mazowieckiego obejmujących: przebudowę dróg } \\
\text { wojewódzkich - nr } 579 \text { Kazuń - Błonie Etap I; nr } 580 \text { na odcinku granica } \\
\text { Warszawy - Leszno Etap I ill; nr } 630 \text { Nowy Dwór Mazowiecki - Jabłonna; } \\
\text { — } \text { M.st. Warszawy obejmujących budowęTrasy Siekierkowskiej odcinek IIB od węzła } \\
\text { Bora Komorowskiego do ulicy Płowieckiej; modernizację Ronda Starzyńskiego; } \\
\text { Zintegrowany System Zarządzania Ruchem; } \\
\text { - Tramwajów Warszawskich Sp. z o. o. obejmujących modernizację trasy } \\
\text { tramwajowej w Alejach Jerozolimskich na odcinku pętla Banacha - pętla } \\
\text { Gocławek; rozbudowę trasy tramwajowej Bemowo - Młociny; } \\
\text { - } \text { realizowanych przez inne jednostki samorządu terytorialnego, tj.: przebudowę } \\
\text { drogi powiatowej - ul. Starokrakowskiej i Krychnowickiej w Radomiu - III etap; } \\
\text { przebudowę ulicy Witosa w Radomiu; budowę obwodnicy w Ostrołęce } \\
\text { (ul. Bohaterów Warszawy, ul. Bohaterów Westerplatte) }\end{array}$ \\
\hline $\begin{array}{c}\text { Ochrona } \\
\text { środowiska }\end{array}$ & $\begin{array}{l}\text { Najważniejsze inwestycje obejmowały: rozbudowę sieci wodociągowo-kanalizacyjnej } \\
\text { w Józefowie; rozbudowę oczyszczalni ścieków wraz z budową sieci kanalizacyjnej } \\
\text { w gminie Stare Babice; przebudowę i modernizację obwałowań rzeki Wisły, gm. } \\
\text { Maciejowice; budowę oczyszczalni ścieków i kanalizacji gminy Klembów; rozbudowę } \\
\text { i modernizację sieci kanalizacji sanitarnej oraz oczyszczalni ścieków w Sochaczewie }\end{array}$ \\
\hline
\end{tabular}

\footnotetext{
${ }^{14}$ Program służył realizacji Narodowego Planu Rozwoju / Podstaw Wsparcia Wspólnoty na lata 2004-2006 (NPR/CSF). WNPR był podstawą do podpisania z Komisja Europejską memorandów finansowych na finansowanie projektów, wdrażanych w ramach projektów operacyjnych na poziomie wojewódzkim.
} 
Tabela 4. cd. Przykładowe projekty zrealizowane w ramach ZPORR

\begin{tabular}{|c|l|}
\hline Obszar & \multicolumn{1}{|c|}{ Inwestycje (przykładowe) } \\
\hline \multirow{5}{*}{$\begin{array}{c}\text { Infrastruktura } \\
\text { społeczna }\end{array}$} & $\begin{array}{l}\text { Soposażono w sprzęt medyczny m.in.: Centralny Szpital Kliniczny MSWiA w Warszawie; } \\
\text { Ginekologiczódzki w Ciechanowie; Wojewódzki Szpital Zespolony w Płocku; Szpital } \\
\text { Opieki Zdrowotnej; Radomski Szpital Specjalistyczny; Wojewódzki Szpital Chirurgii } \\
\text { Urazowej św. Anny; Szpitalny Oddział Ratunkowy WIM; Centrum Rehabilitacji STOCER } \\
\text { SP ZOZ w Konstancinie-Jeziornie; Szpital Kolejowy SP ZOZ w Pruszkowie; Oddział } \\
\text { Kardiologii Szpitala Wolskiego w Warszawie; Wojewódzki Szpital Specjalistyczny } \\
\text { w Siedlcach; Samodzielny Publiczny Zespół Opieki Zdrowotnej w Mińsku }\end{array}$ \\
\hline Szkolnictwo \\
wyższe & $\begin{array}{l}\text { Ważne inwestycje obejmowały: budowę Centrum Edukacji i Badań Interdyscyplinarnych } \\
\text { UKSW w Warszawie; rewaloryzację Pałacu Ogińskich w Siedlcach - Rozwój Instytutu } \\
\text { Informatyki Akademii Podlaskiej; rozbudowę bazy dydaktycznej Państwowej Wyższej } \\
\text { Szkoły Zawodowej w Ciechanowie; modernizację budynku B Wydziału Zarządzania UW; } \\
\text { budowę obiektu naukowo-dydaktycznego WPiA UW; budowę i wyposażenie budynku } \\
\text { dydaktycznego Szkoły Głównej Służby Pożarniczej w Warszawie }\end{array}$ \\
\hline
\end{tabular}

Źródło: opracowanie MBPR w Warszawie

W ramach Regionalnego Programu Operacyjnego Województwa Mazowieckiego 2007-2013 (RPO WM 2007-2013) $)^{15}$ podpisano 2412 umów na łączną kwotę 13,6 mld zł (3,1 mld euro). Wartość dofinansowania z Europejskiego Funduszu Rozwoju Regionalnego (EFRR) wyniosła ok. 7,6 mld zł (ok. 1,7 mld euro). W Indykatywnym Wykazie Projektów Kluczowych (IWPK) $)^{16}$ znajdowało się 126 projektów na kwotę prawie 6 mld złotych, z czego dofinansowanie wynosiło prawie 3,7 mld zł (z EFRR). Najważniejsze inwestycje zawarto w tabeli 5.

W ramach priorytetu I Tworzenie warunków dla rozwoju potencjału innowacyjnego i przedsiębiorczości na Mazowszu zrealizowano działania z zakresu wzmocnienia sektora badawczo-rozwojowego, budowy sieci współpracy nauka - gospodarka, kompleksowego przygotowania terenów pod działalność gospodarcza, wzmocnienia instytucji otoczenia biznesu; rozwoju przedsiębiorczości oraz wspierania powiązań kooperacyjnych o znaczeniu regionalnym. Zrealizowano 36 projektów ujętych w IWPK oraz 1184 konkursowych. Wsparte zostały inwestycje służące potrzebom badań naukowych lub prac rozwojowych, $\mathrm{w}$ tym inwestycje $\mathrm{w}$ infrastrukturę naukowo-badawczą jednostek naukowych i szkół wyższych. W ramach priorytetu II Przyspieszenie e-Rozwoju Mazowsza zrealizowano działania z zakresu wspierania rozwoju społeczeństwa informacyjnego, dotyczące 8 projektów ujętych w IWPK oraz 255 konkursowych. Dostęp do Internetu uzyskało 397 podmiotów oraz ponad $2 \mathrm{mln}$ osób, uruchomiono 2011 usług on-line.

\footnotetext{
${ }^{15}$ Dane pochodzą ze Sprawozdania końcowego z realizacji Regionalnego Programu Operacyjnego Województwa Mazowieckiego 2007-2013.

${ }^{16}$ Szerzej: Indywidualne projekty kluczowe RPO WM 2007-2013 a realizacja celów SRWM, Mazowsze. Analizy i Studia, 5, 46, 2015, Warszawa.
} 


\begin{tabular}{|c|c|}
\hline Obszar & Inwestycje (przykładowe) \\
\hline $\begin{array}{l}\text { Badania } \\
\text { i rozwój }\end{array}$ & $\begin{array}{l}\text { Najważniejsze projekty dotyczyły: wyposażenia w nowoczesną aparaturę ba- } \\
\text { dawczo-naukową Centrum grafenu i innowacyjnych nanotechnologii Instytutu } \\
\text { Technologii Materiałów Elektronicznych (ITME); budowy Centrum Innowacyjnych } \\
\text { Technologii Lotniczych i Kosmicznych (Instytut Lotnictwa); wzmocnienie bazy in- } \\
\text { frastrukturalnej i aparaturowej Narodowego Centrum Badań Jądrowych (NCBJ) } \\
\text { kluczowej dla rozwoju technologii wykorzystujących promieniowanie; budowy } \\
\text { i utworzenia Centrum Badawczego PAN w Jabłonnie; zakupu aparatury na po- } \\
\text { trzeby Weterynaryjnego Centrum Badawczego (SGGW), rozbudowy laboratoriów } \\
\text { i stworzenia prototypów linii doświadczalnych Instytutu Wysokich Ciśnień PAN; } \\
\text { utworzenia Centrum Zarządzania Innowacjami i Transferem Technologii Politechniki } \\
\text { Warszawskiej, budowy obiektów Płockiego Parku Przemysłowo-Technologicznego } \\
\text { (PPP-T), Parku Naukowo-Technologicznego w Świerku oraz Parku Innowacyjnego } \\
\text { Celestynów Unipress. }\end{array}$ \\
\hline e-rozwój & $\begin{array}{l}\text { Najważniejsze projekty: Internet dla Mazowsza; e-zdrowie dla Mazowsza; } \\
\text { Modernizacja i rozbudowa sieci teleinformatycznej Urzędu m.st. Warszawy Rozwój } \\
\text { e-usług i ich dostępu dla obywateli w ramach Mazowieckiej Sieci Społeczeństwa } \\
\text { Informacyjnego „M@zowszanie”; Rozwój elektronicznej administracji w samorzq- } \\
\text { dach województwa mazowieckiego wspomagającej niwelowanie dwudzielności po- } \\
\text { tencjału województwa; e-usługi w ochronie zdrowia (Szpital Kliniczny im. Ks. Anny } \\
\text { Mazowieckiej). }\end{array}$ \\
\hline $\begin{array}{l}\text { Regionalny system } \\
\text { transportowy }\end{array}$ & $\begin{array}{l}\text { Koleje Mazowieckie - KM Sp. z o.o., należące do województwa mazowieckiego, } \\
\text { zakupiły } 11 \text { lokomotyw elektrycznych. Warszawska Kolej Dojazdowa Sp. z o.o. } \\
\text { zakupiła kolejowy tabor pasażerski do obsługi połączeń regionalnych na linii } \\
\text { Warszawskiej Kolei Dojazdowej w Warszawskim Obszarze Metropolitalnym. } \\
\text { Uruchomiono Mazowiecki Port Lotniczy Warszawa-Modlin. } \\
\text { Dofinansowano kluczowe inwestycje w zakresie: budowy nowych połączeń dro- } \\
\text { gowych, tj. budowy nowego przebiegu dróg wojewódzkich nr } 627 \text { i 728; prze- } \\
\text { budowy istniejących dróg wojewódzkich nr 617, 637, 724, 732, 631, } 728 \text { i 727; } \\
\text { budowy obwodnic w Siedlcach i Radomiu; realizacji inwestycji ułatwiających ruch } \\
\text { w miastach - w Ciechanowie; Płocku, Warszawie; przebudowy węzłów i skrzyżo- } \\
\text { wań; budowy obiektów mostowych - most przez rzekę Jeziorkę w Konstancinie- } \\
\text { Jeziornie oraz modernizacja wiaduktu nad torami PKP w ciągu ul. Powązkowskiej } \\
\text { w Warszawie. Na wyróżnienie zasługuje projekt „Odbudowa dróg gminnych”: G5, } \\
\text { G9, G30, G37, G38, G39, G42, G45, uszkodzonych w wyniku powodzi w } 2010 \text { r. na } \\
\text { terenie gminy Słubice. }\end{array}$ \\
\hline $\begin{array}{c}\text { Środowisko, zapobiega- } \\
\text { nie zagrożeniom } \\
\text { i energetyka }\end{array}$ & $\begin{array}{l}\text { Najważniejszymi projektami związanymi z gospodarką wodno-ściekową były } \\
\text { projekty chroniące Kampinoski Park Narodowy (rozbudowa oczyszczalni ścieków } \\
\text { Mokre Łąki w Truskawiu wraz z budową kanalizacji sanitarnej i sieci wodociągo- } \\
\text { wej w Gminie Izabelin) oraz Jezioro Zegrzyńskie (system kanalizacyjny na tere- } \\
\text { nach Gmin Nieporęt i Serock - opaska kanalizacyjna Jeziora Zegrzyńskiego wraz } \\
\text { z pompowniami i oczyszczalnią ścieków w miejscowości Dębe). Ważne projekty } \\
\text { dotyczyły uporządkowania gospodarki ściekowej zlewni jezior Ciechomickiego, } \\
\text { Górskiego i Zdworskiego (gmina Łąck) oraz budowy kanalizacji i oczyszczalni } \\
\text { w gminach Żabia Wola, Wiskitki, Mszczonów i Puszcza Mariańska. }\end{array}$ \\
\hline
\end{tabular}


Tabela 5. cd. Przykładowe projekty zrealizowane z RPO WM 2007-2013

\begin{tabular}{|c|c|}
\hline Obszar & Inwestycje (przykładowe) \\
\hline $\begin{array}{l}\text { Środowisko, zapobiega- } \\
\text { nie zagrożeniom } \\
\text { i energetyka }\end{array}$ & $\begin{array}{l}\text { W zakresie budowy, modernizacji i poprawy stanu technicznego urządzeń } \\
\text { przeciwpowodziowych wybrane zostały projekty: Przebudowa wału przeciw- } \\
\text { powodziowego prawobrzeżnej doliny Wisty na odcinku Baczki - Antoniówka } \\
\text { Świerzowska gm. Maciejowice; Przebudowa wału przeciwpowodziowego rzeki Wisły } \\
\text { w gm. Czosnów oraz Remont zapory bocznej Jeziora Zegrzyńskiego Kania-Popowo. } \\
\text { Projekt Udrożnienie ujściowego odcinka rzeki Bug od ujścia do rz. Narew związany } \\
\text { był z utrzymywaniem w dobrym stanie rzek oraz związanej z nimi infrastruktury. } \\
\text { Natomiast projekt Wsparcie systemu ratowniczo-gaśniczego na terenie wojewódz- } \\
\text { twa mazowieckiego poprzez zakup specjalistycznego sprzętu w zakresie zapobiega- } \\
\text { nia i ograniczania skutków zagrożeń naturalnych oraz przeciwdziałania poważnym } \\
\text { awariom przyczynia się do wzrostu bezpieczeństwa publicznego. }\end{array}$ \\
\hline Rewitalizacja & $\begin{array}{l}\text { Rewitalizacja: Rynku Mariackiego w Węgrowie, Bazyliki Archikatedralnej } \\
\text { i Muzeum Archidiecezji Warszawskiej, zespołu zamkowo-parkowego, Skweru } \\
\text { Staromiejskiego, Parku Radziwiłłowskiego w Szydłowcu, zabytkowego budynku } \\
\text { dawnego kolegium i dawnej kolegiaty św. Michała w Płocku, obiektów WITD } \\
\text { w Radomiu. }\end{array}$ \\
\hline $\begin{array}{l}\text { Dziedzictwo } \\
\text { i Kultura }\end{array}$ & $\begin{array}{l}\text { Najważniejsze projekty dotyczyły: utworzenia ośrodka wydarzeń kulturalnych } \\
\text { wraz z salą widowiskowo-edukacyjną Europejskiego Centrum Promocji Kultury } \\
\text { Regionalnej i Narodowej „Matecznik Mazowsze” w Otrębusach (gm. Brwinów); re- } \\
\text { witalizacji zabytkowego zespołu pałacowo-parkowego Karolin w Otrębusach (gm. } \\
\text { Brwinów), restauracji barokowego kościoła św. Krzyża w Warszawie z I połowy } \\
\text { XVI wieku, poprawy warunków ekspozycyjnych Cytadeli Warszawskiej- Muzeum } \\
\text { Niepodległości w Warszawie; przeprowadzenia prac modernizacyjnych i konser- } \\
\text { wacyjnych wnętrz i elewacji Teatru Polskiego im. Arnolda Szyfmana w Warszawie; } \\
\text { budowy centrum kulturalno-rekreacyjnego w Muzeum Wsi Mazowieckiej } \\
\text { w Sierpcu, rozbudowy i modernizacji infrastruktury uzdrowiskowej Konstancina- } \\
\text { Zdrój. }\end{array}$ \\
\hline $\begin{array}{l}\text { Infrastruktura służąca } \\
\text { ochronie zdrowia i życia }\end{array}$ & $\begin{array}{l}\text { Dofinasowanie przeznaczono m.in. na: rozbudowę Wojewódzkiego Szpitala } \\
\text { Zespolonego w Płocku; budowę pawilonu ginekologiczno-położniczego } \\
\text { w Radomskim Szpitalu Specjalistycznym im. dr. Tytusa Chałubińskiego; moder- } \\
\text { nizację systemu neuronawigacji w samodzielnym publicznym specjalistycznym } \\
\text { szpitalu zachodnim im. Jana Pawła II w Grodzisku Mazowieckim; zakup innowa- } \\
\text { cyjnego sprzętu dla Mazowieckiego Szpitala Bródnowskiego Sp. zo.o. }\end{array}$ \\
\hline Szkolnictwo wyższe & $\begin{array}{l}\text { Ważne projekty dotyczyły budowy lub przebudowy budynków: Wydziału } \\
\text { Humanistycznego z Pracownią Rzeźby dla Uniwersytetu Przyrodniczo- } \\
\text { Humanistycznego w Siedlcach; Wydziału Lingwistyki Stosowanej oraz Wydziału } \\
\text { Neofilologii Uniwersytetu Warszawskiego; PaństwowejWyższej Szkoły Zawodowej } \\
\text { w Płocku; Nauczycielskiego Kolegium Języków Obcych w Siedlcach. }\end{array}$ \\
\hline
\end{tabular}

Źródło: opracowanie MBPR w Warszawie 
W ramach priorytetu III Regionalny system transportowy zrealizowano projekty mające na celu poprawę spójności komunikacyjnej i przestrzennej województwa mazowieckiego oraz wspomaganie dyfuzji procesów rozwojowych z głównego ośrodka regionu - Warszawy oraz z ośrodków subregionalnych na pozostałe obszary województwa, przede wszystkim w zakresie poprawy standardu i jakości regionalnej sieci drogowej oraz bezpieczeństwa ruchu drogowego, poprawy dostępności i jakości usług w zakresie regionalnego transportu publicznego oraz rozwoju regionalnego transportu lotniczego. Zrealizowano 28 projektów ujętych w IWPK oraz 260 konkursowych.

W ramach priorytetu IV Środowisko, zapobieganie zagrożeniom i energetyka zrealizowano inwestycje mające wpływ na poprawę stanu środowiska naturalnego, szczególnie obejmujące budowę bądź modernizację infrastruktury ograniczającej emisję i negatywne skutki zanieczyszczeń. Rozbudo wywano i modernizowano także infrastrukturę elektroenergetyczną i ciepłowniczą regionu, odnawialnych źródeł energii, zapobiegania zagrożeń naturalnych i katastrof ekologicznych. Zarząd Województwa Mazowieckiego zaakceptował do realizacji 14 projektów kluczowych -8 z zakresu gospodarki wodnościekowej, 1 dotyczący ochrony powierzchni ziemi, 5 związanych z przeciwdziałaniem zagrożeniom naturalnym oraz 180 projektów konkursowych. Długość sieci wodociągowej wzrosła o 669,1 km, a sieci kanalizacyjnej o 946,2 km, przyłączając tym samym 30,6 tys. osób do sieci wodociągowej i 43,8 tys., osób do sieci kanalizacyjnej. Na Mazowszu zrealizowano 67 projektów dotyczących termomodernizacji budynków użyteczności publicznej wraz z wymianą wyposażenia tych obiektów na energooszczędne (łączna kwota dofinansowania UE - 52,5 mln euro). W wyniku udzielonego wsparcia, ochroną przeciwpowodziową objęto obszar 51,2 tys. ha, co pozwoliło zabezpieczyć przed powodzią 150,3 tys. osób. O wyrównywaniu dysproporcji $\mathrm{w}$ rozwoju społeczno-gospodarczym pomiędzy poszczególnymi częściami województwa świadczy fakt, że 97 z 194 projektów wdrażanych było na obszarach problemowych wyznaczonych $\mathrm{w}$ Strategii rozwoju województwa mazowieckiego do roku 2020. Procent wartości dofinansowania w części EFRR tych projektów wyniósł $47 \%$ (w ujęciu wartościowym). Największy odsetek umów zrealizowano w obszarze ostrołęckim - 26, nadbużańskim - 24 i radomskim - 22.

W priorytecie $\mathrm{V}$ Wzmacnianie roli miast w rozwoju regionu znalazły się projekty nakierowane na wykorzystanie potencjału endogenicznego miast w celu aktywizacji społecznogospodarczej regionu w transporcie miejskim i rewitalizacja miast odnosząca się do obszarów zdegradowanych i zagrożonych marginalizacją. W zakresie unowocześniania transportu miejskiego wykonano 10 projektów przyczyniających się do poprawy funkcjonowania transportu miejskiego. $\mathrm{Z}$ zakresu rewitalizacji zrealizowano 28 projektów konkursowych, obejmujących 20,0 ha.

W ramach priorytetu VI Wykorzystanie walorów naturalnych $i$ kulturowych dla rozwoju turystyki i rekreacji, zrealizowano 21 projektów dotyczących poprawy oferty kulturalnej i wzrostu dostępności do kultury oraz 7 w zakresie promocji i zwiększania atrakcyjności turystycznej regionu, a także 96 projektów konkursowych. Przyczyniły się one do rozwoju turystyki i kultury w miastach i na obszarach wiejskich. W obszarze kultury wsparty został 
rozwój infrastruktury, m.in. poprzez budowę, rozbudowę lub modernizację budynków i obiektów instytucji kultury. Wybudowano lub zmodernizowano 151 obiektów kultury i dziedzictwa.

Poprzez realizację inwestycji ujętych w działaniu Turystyka możliwy stał się rozwój infrastruktury turystycznej. Zrealizowano 7 projektów kluczowych oraz 212 konkursowych. Wybudowano 169 obiektów turystycznych i rekreacyjnych, a przebudowano 41. Powstało 1144,8 km szlaków turystycznych, 668,8 km ścieżek rowerowych, utworzono 71 turystycznych portali informacyjnych oraz 565 nowych produktów turystycznych.

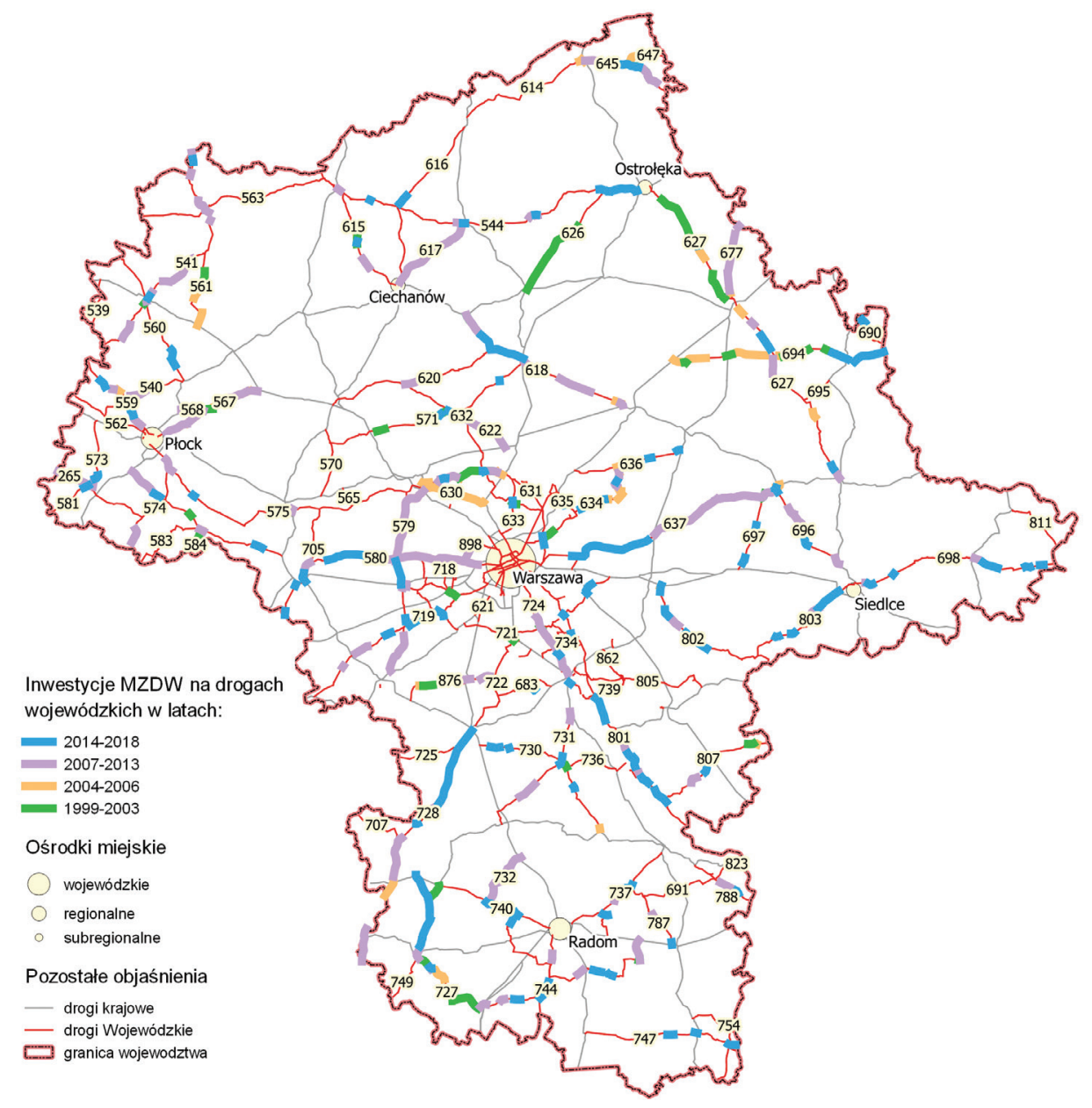

Ryc. 1. Wojewódzkie inwestycje drogowe

Źródło: opracowanie MBPR w Warszawie 
W ramach priorytetu VII Tworzenie i poprawa warunków dla rozwoju kapitału ludzkiego zrealizowane zostały ważne inwestycje w zakresie poprawy stanu i dostępności infrastruktury ochrony zdrowia i służącej edukacji. W działaniu Infrastruktura służaca ochronie zdrowia $i$ życia Zarząd Województwa Mazowieckiego wybrał do realizacji 17 kluczowych projektów, mających na celu poprawę stanu infrastruktury i doposażenie w sprzęt medyczny lecznictwa otwartego i zamkniętego. Wykonano również 35 projektów konkursowych. Zakupiony sprzęt medyczny umożliwił przeprowadzenie 863,5 tys. specjalistycznych badań medycznych rocznie. Projekty dotyczące działania Infrastruktura stużąca edukacji ukierunkowane były na tworzenie bazy dydaktycznej, przyczyniającej się do wyrównywania szans edukacyjnych, do wzrostu konkurencyjności regionu i rozwoju kapitału ludzkiego w województwie. Wsparto 4 projekty kluczowe. Zrealizowano także 85 inwestycji wybranych w konkursach. Łącznie zostało wspartych 306 placówek edukacyjnych na Mazowszu, z których korzysta 97,8 tys. uczniów i studentów. Również w ramach Priorytetu VII zostały wsparte projekty dotyczące infrastruktury opieki społecznej. Zbudowano, przebudowano lub doposażono 26 obiektów infrastruktury społecznej, co pozwoliło na utworzenie czy utrzymanie 985 miejsc w powstałych obiektach służących opiece społecznej.

Na Mazowszu stale wzrastała liczba wojewódzkich inwestycji drogowych - w latach 1999-2017 zrealizowano ich 505 (ryc. 1). Inwestycje drogowe nastawione były na poprawę przepustowości najważniejszych korytarzy transportowych. W wielu przypadkach przebudowano drogi na całej długości ich przebiegu, np.: 617, 637, 732. Zmienia się także podejście do inwestycji drogowych - na kompleksowe, czego przykładem jest ciąg dróg 801, 728, 727, 694, zrealizowanych w kolejnych okresach programowania. Przebudowa drogi 617 na odcinku Ciechanów - Przasnysz konieczna była ze względu na duże natężenie ruchu oraz znaczenie tej trasy na poziomie lokalnym. Przebudowa drogi 637, na odcinku Warszawa Węgrów oraz drogi 580 Warszawa - Sochaczew, zwiększyły dostępność do stolicy. Pomimo ponoszonych dużych nakładów finansowych przez samorząd województwa w infrastrukturę drogowa, wśród nierozwiązanych problemów, pozostaje nadal niewystarczająca liczba obwodnic miast.

W okresie programowania 2014-2020 inwestycje rozwojowe są realizowane głównie w ramach Regionalnego Programu Operacyjnego Województwa Mazowieckiego 2014-2020 (RPO WM 2014-2020). Całkowita wartość dofinansowania unijnego, dostępnego w ramach programu, wynosi ponad 2 mld euro, czyli ponad $8 \mathrm{mld}$ zł, z czego trzy czwarte to środki z Europejskiego Funduszu Rozwoju Regionalnego, a jedna czwarta pochodzi z Europejskiego Funduszu Społecznego. Biorąc pod uwagę, że maksymalna stopa dofinansowania wynosi $80 \%$, takie środki pozwolą na realizację inwestycji o łącznej wartości przekraczającej 10 mld zł.

Część środków przeznaczona jest na działania realizowane w ramach Zintegrowanych Inwestycji Terytorialnych. Jednym z takich działań jest budowa Wirtualnego Warszawskiego Obszaru Funkcjonalnego, składającego się z rozwiązań mobilnych w pięciu obszarach: e-dostępność, e-turystyka, e-transport publiczny, e-parkowanie, e-środowisko. Projekt ten otrzymał dofinansowanie w wysokości 56 mln zł (80\% kosztów). 
Z inicjatywy Samorządu Województwa Mazowieckiego w ramach RPO WM 20142020, równolegle do ZIT, uruchomione zostały Regionalne Inwestycje Terytorialne (RIT) w obszarach wokół pozostałych miast regionalnych i subregionalnych. Są to narzędzia motywujące do koordynacji działań i współpracy pomiędzy lokalnymi jednostkami samorządu terytorialnego.

W ramach aktualnego regionalnego programu operacyjnego, w połowie kwietnia 2018 r., podpisano już ponad 2000 umów na dofinansowanie projektów środkami w wysokości ponad 4,8 mld zł. Oznacza to, że zakontraktowano już większość dostępnych funduszy. Wśród projektów wybranych $\mathrm{w}$ trybie pozakonkursowym należy wspomnieć o przedsięwzięciach mających wpływ na warunki podróży w województwie, w tym modernizacji 39 elektrycznych zespołów trakcyjnych przez Koleje Mazowieckie (projekt o wartości 198 $\mathrm{mln}$ zł, z czego $128 \mathrm{mln}$ zł pozyskanych zostało z RPO WM). Ponadto dofinansowanie otrzymały inwestycje w system opieki zdrowotnej, w tym budowa szpitala psychiatrycznego w Ząbkach, w sąsiedztwie istniejącej placówki w Drewnicy, jako najnowocześniejszego szpitala psychiatrycznego w Polsce. Ze środków RPO WM pokryto 70\% kosztów budowy (95,8 mln zł) w podwarszawskich Ząbkach.

Realizowane są także ważne projekty $\mathrm{z}$ obszaru $\mathrm{B}+\mathrm{R}$, tj.: Utworzenie Ośrodka Inteligentnych Specjalizacji w zakresie Innowacyjnych Technologii Przemysłowych oraz Bezpieczeństwa Technicznego i Środowiskowego; Centrum Prototypowania ITeE-PIB; Centrum Żywności i Żywienia - modernizacja kampusu SGGW w celu stworzenia Centrum Badawczo-Rozwojowego Żywności i Żywienia (CŻiŻ); Centrum Bezpieczeństwa Transportu i Diagnostyki Pojazdów; Mazowieckie Centrum Badawczo-Rozwojowe Diagnostyki Matki i Dziecka; Centrum Badań Przedklinicznych i Technologii - CePT II; Utworzenie Centralnego Laboratorium Mechaniki i Budownictwa w Płocku; Multidyscyplinarne Centrum Badawcze Uniwersytetu Kardynała Stefana Wyszyńskiego w Warszawie; Utworzenie Centrum Informacyjno-Wdrożeniowego Przemysłowych Technik Radiacyjnych CentriX.

Bank Gospodarstwa Krajowego, w ramach projektu pn. Instrumenty finansowe dla mazowieckich MŚP, wspiera rozwój przedsiębiorstw z sektora MŚP realizujących inwestycje prowadzące do wzrostu ich konkurencyjności i innowacyjności. Grupą docelową projektu będą mikro, małe i średnie przedsiębiorstwa z terenu województwa mazowieckiego.

Województwo mazowieckie podpisało z Rządem RP Kontrakt terytorialny, w którym ujęto inwestycje ważne z punktu rozwoju kraju i województwa (tabela 6). Umieszczenie przedsięwzięć na liście KT nie gwarantuje jednak ich realizacji - uzależnione jest od możliwości finansowych programów rządowych i RPO WM 2014-2020. 
Tabela 6. Kontrakt terytorialny 2014-2023 - wybrane projekty

\begin{tabular}{|c|c|}
\hline $\begin{array}{l}\text { Obszar } \\
\text { tematyczny }\end{array}$ & Wybrane projekty ujęte w Kontrakcie terytorialnym 2014-2023 \\
\hline \multirow{9}{*}{ Kultura } & $\begin{array}{l}\text { Europejskie Centrum Muzyki Sinfonia Varsovia (część dotycząca budynków } \\
\text { zabytkowych) }\end{array}$ \\
\hline & Stacja Muzeum - renowacja i konserwacja zabytkowego taboru kolejowego \\
\hline & Rewitalizacja zabytkowego Pałacyku Briggsów wraz z parkiem w Markach \\
\hline & $\begin{array}{l}\text { Rewitalizacja zabytkowego Kościoła pw. Wszystkich Świętych w Warszawie dla } \\
\text { zachowania dziedzictwa kulturowego i poprawy dostępności do zasobów kultury }\end{array}$ \\
\hline & $\begin{array}{l}\text { Rewaloryzacja parku miejskiego - historycznego założenia ogrodowego „Aleksandria” } \\
\text { w Siedlcach }\end{array}$ \\
\hline & $\begin{array}{l}\text { Renowacja zabytkowej oficyny, budynku wieży, zbiornika fontanny w Zespole Pałacowo- } \\
\text { Parkowym w Kozienicach - etap II i etap III }\end{array}$ \\
\hline & $\begin{array}{l}\text { Rewitalizacja nieruchomości przy ul. Rwańska 2/Rynek } 15 \text { oraz Rwańska 4/Rynek 14/ } \\
\text { Grodzka } 1 \text { w Radomiu }\end{array}$ \\
\hline & Modernizacja skrzydła północnego i wschodniego Warszawskiego Arsenału \\
\hline & $\begin{array}{l}\text { Odrestaurowanie Pałacyku Karolin i utworzenie bazy edukacyjnej dla prezentacji } \\
\text { i promocji folkloru }\end{array}$ \\
\hline \multirow{12}{*}{ Transport } & $\begin{array}{l}\text { Budowa drogi wojewódzkiej „Paszkowianki” łączącej drogę krajową nr } 8 \text { z autostradą } \\
\text { A2, od skrzyżowania z drogą wojewódzką nr } 719 \text { do autostrady A2. }\end{array}$ \\
\hline & $\begin{array}{l}\text { Budowa drogi wojewódzkiej nr } 801 \text { po nowym śladzie na odcinku od granic Warszawy } \\
\text { do skrzyżowania z DW } 721 \text { (odcinek o długości ok. } 4 \text { km) oraz rozbudowa drogi na od- } \\
\text { cinkach o łącznej długości } 67,2 \mathrm{~km}\end{array}$ \\
\hline & $\begin{array}{l}\text { Rozbudowa DW } 637 \text { na odcinku od granicy Warszawy do m. Stanisławów wraz z budową } \\
\text { obwodnicy m. Stanisławów }\end{array}$ \\
\hline & Rozbudowa DW 634 (odcinek od DW 631 do Wołomina) \\
\hline & $\begin{array}{l}\text { Budowa nowego przebiegu obwodnicy centrum Gąbina w ciągu drogi wojewódzkiej } \\
\text { nr } 577 \text { relacji Łąck-Ruszki, na terenie m. Gąbin }\end{array}$ \\
\hline & $\begin{array}{l}\text { Budowa drogi wojewódzkiej na odcinku od drogi wojewódzkiej nr } 560 \text { do drogi } \\
\text { krajowej nr } 10 \text { w rejonie } \mathrm{m} \text {. Sierpc }\end{array}$ \\
\hline & Obwodnica Grodziska Mazowieckiego w ciągu DW 579 \\
\hline & Inwestycje w zaplecza techniczne dla obsługi taboru kolejowego \\
\hline & Budowa linii kolejowej w relacji Płock-Modlin \\
\hline & $\begin{array}{l}\text { Budowa odcinka linii kolejowej od stacji Modlin do Mazowieckiego Portu Lotniczego } \\
\text { (MPL) Warszawa/Modlin oraz budowa stacji kolejowej Mazowiecki Port Lotniczy (MPL) } \\
\text { Warszawa/Modlin }\end{array}$ \\
\hline & Rewitalizacja linii kolejowej nr 33 Kutno - Płock \\
\hline & Prace na linii kolejowej nr 29 odcinek Mostówka - Ostrołęka \\
\hline
\end{tabular}


112 REALIZACJA POLITYKI ROZWOJU WOJEWÓDZTWA MAZOWIECKIEGO...

Adam Struzik

Tabela 6. cd. Kontrakt terytorialny 2014-2023 - wybrane projekty

\begin{tabular}{|c|c|}
\hline $\begin{array}{l}\text { Obszar } \\
\text { tematyczny }\end{array}$ & Wybrane projekty ujęte w Kontrakcie terytorialnym 2014-2023 \\
\hline \multirow{5}{*}{ Transport } & Prace na linii kolejowej nr 36 odcinek Ostrołęka - Śniadowo \\
\hline & $\begin{array}{l}\text { Modernizacja linii kolejowej nr } 35 \text { na odcinku Ostrołęka - Chorzele oraz budowa linii } \\
\text { kolejowej łączącej linię nr } 35 \text { z linią nr } 9 \text { na odcinku Ciechanów - Przasnysz - Chorzele }\end{array}$ \\
\hline & $\begin{array}{l}\text { Budowa centrum logistycznego wraz z drogowo-kolejowym węzłem przesiadkowym, } \\
\text { modernizacją dworca kolejowego, infrastrukturą towarzyszącą oraz bocznicą towarową } \\
\text { w Ciechanowie }\end{array}$ \\
\hline & $\begin{array}{l}\text { Kompleksowe przedsięwzięcia z zakresu zrównoważonej mobilności miejskiej/ } \\
\text { ekologicznego transportu }\end{array}$ \\
\hline & $\begin{array}{l}\text { Zakup pojazdów niskoemisyjnych na potrzeby transportu zbiorowego w Radomiu wraz } \\
\text { z niezbędną infrastrukturą towarzyszącą i systemami zarządzania ruchem }\end{array}$ \\
\hline \multirow{3}{*}{ Środowisko } & Pakiet inwestycji z zakresu gospodarki wodnej \\
\hline & Pakiet inwestycji wodno-kanalizacyjnych na terenie Mazowsza \\
\hline & Pakiet inwestycji z zakresu gospodarowania odpadami \\
\hline \multirow{3}{*}{ Zdrowie } & $\begin{array}{l}\text { Poprawa funkcjonowania i efektywności kosztowej leczenia psychiatrycznego } \\
\text { w Mazowieckim Szpitalu Wojewódzkim Drewnica }\end{array}$ \\
\hline & Tworzenie i rozwój ośrodków geriatrycznych (projekt systemowy) \\
\hline & $\begin{array}{l}\text { Tworzenie i rozwój ośrodków onkologicznych (projekt systemowy), w tym Siedleckiego } \\
\text { Ośrodka Onkologicznego }\end{array}$ \\
\hline \multirow{10}{*}{$\mathrm{B}+\mathrm{R}$} & Centrum grafenu i innowacyjnych nanotechnologii \\
\hline & Utworzenie Mazowieckiego Centrum Fotoniki Stosowanej - CEFOS \\
\hline & $\begin{array}{l}\text { Mazowieckie Centrum Funkcjonalnych Materiałów Hybrydowych i Energii (EnPol High- } \\
\text { Tech) }\end{array}$ \\
\hline & $\begin{array}{l}\text { Narodowe Centrum Chemii (NCC) w ramach klastra "Mazowiecka Dolina Zielonej } \\
\text { Chemii" (MDZCh) }\end{array}$ \\
\hline & $\begin{array}{l}\text { Utworzenie Centrum innowacyjno-wdrożeniowego przemysłowych technik } \\
\text { radiacyjnych-CentriX }\end{array}$ \\
\hline & Wrota Mokotowa. Zadanie A: Centrum Badań i Innowacji \\
\hline & $\begin{array}{l}\text { Centrum Naukowych Analiz Geoprzestrzennych, Obliczeń Satelitarnych wraz } \\
\text { z laboratoriami Testowania/Certyfikacji Produktów Geomatycznych } \\
\text { CENAGIS }\end{array}$ \\
\hline & Centrum Biologii Stosowanej (CeBioS) \\
\hline & $\begin{array}{l}\text { Utworzenie Centrum Badawczego PAN „Konwersja Energii i Źródła Odnawialne” } \\
\text { w Gminie Jabłonna - Il etap, Smart E+, Demonstrator Inteligentnych (Smart) Technologii } \\
\text { Plus-Energetycznych (E+) w małoskalowej i rozproszonej energetyce odnawialneji }\end{array}$ \\
\hline & Centrum Nanoelektroniki, Mikrosystemów i Fotoniki \\
\hline
\end{tabular}




\begin{tabular}{|c|c|}
\hline $\begin{array}{l}\text { Obszar } \\
\text { tematyczny }\end{array}$ & Wybrane projekty ujęte w Kontrakcie terytorialnym 2014-2023 \\
\hline \multirow{6}{*}{$\mathrm{B}+\mathrm{R}$} & Laboratorium Zaawansowanych Technologii IPPT PAN (LZT-IPPT) \\
\hline & $\begin{array}{l}\text { Utworzenie Pracowni Przewrotu Kopernikańskiego działającej w ramach Centrum } \\
\text { Nauki Kopernik }\end{array}$ \\
\hline & Centrum Prototypowania ITeE-PIB \\
\hline & $\begin{array}{l}\text { Laboratorium badawczo-wdrożeniowe technologii robotyki kosmicznej } \\
\text { i bezpieczeństwa }\end{array}$ \\
\hline & Kampus Nowych Technologii. Akcelerator Innowacyjności Politechniki Warszawskiej \\
\hline & $\begin{array}{l}\text { Utworzenie laboratoriów technologiczno-obróbczego oraz materiałowego na } \\
\text { rzecz innowacyjnego przemysłu, jako jednego z elementów Parku Naukowo- } \\
\text { Technologicznego w Radomiu }\end{array}$ \\
\hline
\end{tabular}

Źródło: opracowanie MBPR w Warszawie

\section{Podsumowanie}

Polityka rozwoju w województwie mazowieckim w latach 1999-2017 realizowana była przez władze samorządowe na podstawie przyjętych i aktualnych strategii rozwoju województwa mazowieckiego, planu zagospodarowania przestrzennego województwa oraz programów rozwoju, w tym regionalnego programu operacyjnego. Zrealizowane $\mathrm{w}$ tym okresie inwestycje na obszarze województwa mazowieckiego przyczyniły się do wzrostu jego konkurencyjności, zwiększenia dostępności transportowej, poprawy stanu środowiska naturalnego oraz poprawy jakości życia na obszarze całego regionu - wspierane były zarówno miasta jak i obszary wiejskie.

Doświadczenia samorządu województwa mazowieckiego w zakresie prowadzenia polityki rozwoju potwierdzają słuszność dokonanych zmian związanych z usamodzielnieniem regionów, które poprzez możliwość uzyskiwania środków własnych oraz dostępność do środków z funduszy europejskich są w stanie osiągać ważne cele społeczne. Aktywna polityka władz samorządowych województwa mazowieckiego przyczyniła się do zwiększenia alokacji środków z Unii Europejskiej na okres programowania 2014-2020. Wypracowane przez województwo mazowieckie rozwiązania dotyczące nowego podziału statystycznego, polegające na wyodrębnieniu obszaru metropolitalnego Warszawy na poziomie NUTS-2, niewątpliwie będą miały wpływ na większe dofinansowanie obszarów pozametropolitalnych po roku 2020. Do rozwiązania pozostają jednak ważkie kwestie dotyczące subwencji regionalnej - dlatego też nieustannie podejmowane są działania w celu wypracowania koncepcji korzystniejszych dla województwa mazowieckiego. 
$114 \mid \begin{aligned} & \text { REALIZACJA POLITYKI ROZWOJU WOJEWÓdZTWA MAZOWIECKIEGO... } \\ & \text { Adam StruZik }\end{aligned}$

The implementation of development policy in Mazovia in 1998-2018

\section{ABSTRACT}

The article aims to present an overview of the development policy in Mazovia during the last two decades. First, the changes in the administrative division of Poland in 1998/1999 are discussed along with the legislation which determined the powers of the regional government in terms of implementing development policy. Next, the integrated development policy implemented in Mazovia is presented from a horizontal perspective (integration of strategic and spatial planning documents) and a historical one (consistency in setting and pursuing development goals). The practice of development policy implementation is set against the problems resulting from regional subvention (the so-called "Robin Hood tax"). The article points to progress in this respect, identifying some changes serving to fix the faulty mechanism of redistribution of funds among Polish regions. The distribution of European funds is mentioned when changes in the statistical divison of Mazovia are discussed, as the new NUTS-2 regions have a direct impact on the amount and type of Cohesion Policy support available to Mazovia. Apart from activity on the level of the European Union, the article presents Mazovia's cooperation with other foreign regions and international institutions. The last part of the article discusses the effects of the implementation of Mazovia's development policy in 1998-2018. The actions undertaken in individual programming periods are illustrated through examples of the most important investments and projects and set against contemporary implementation documents.

The article was based on the analysis of data and information collected in the Mazovian Office of Regional Planning. The presentation in one text of information covering two decades of the Mazovian Regional Government's activity has allowed for a new perspective on the effects and added value of the implementation of a consistent development policy in the region.

Key words: regional development, regional government, development policy, Mazovia 